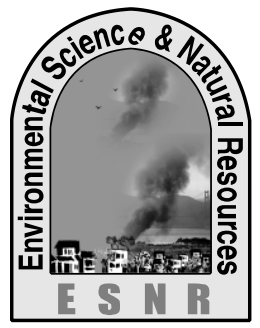

\title{
Effect of Municipal Solid Waste Compost on the Performance of Chilli, Dahlia and Marigold
}

\author{
M. R. Anam ${ }^{1}$, K. Hossen ${ }^{2}$, M. A. $\operatorname{Kader}^{1 *}$, M. M. Billah ${ }^{2}$ and N. Islam ${ }^{1}$ \\ ${ }^{1}$ Department of Agronomy, Bangladesh Agricultural University Mymensingh 2202, Bangladesh, \\ ${ }^{2}$ Department of Agriculture, Noakhali Science and Technology University, Noakhali. \\ "Corresponding author: abdul.kader@bau.edu.bd
}

\begin{abstract}
An experiment was conducted at the Moinar Mor Sabuj Nursery, Mymensingh to evaluate the effects of compost prepared from solid wastes of Mymensingh municipality area on the yield and yield attributes of three crops viz. Chilli, Dahlia and Marigold grown in pots. Each crop was grown under six different treatments viz. $100 \%$ compost $\left(\mathrm{T}_{0}\right), 75 \%$ compost $+25 \%$ soil $\left(\mathrm{T}_{1}\right), 50 \%$ compost $+50 \%$ soil $\left(\mathrm{T}_{2}\right), 25 \%$ compost $+75 \%$ soil $\left(\mathrm{T}_{3}\right), 100 \%$ soil $\left(\mathrm{T}_{4}\right)$ and farmers practice- $\left(\mathrm{T}_{5}\right)(75 \%$ of recommended rate of NPK plus soil). A single factor experiment was laid out in a with three replications. The results revealed that in Chilli, application of $75 \%$ compost plus $25 \%$ soil $\left(\mathrm{T}_{1}\right)$ produced significantly the tallest plant $(45.50 \mathrm{~cm})$, maximum number of flowers $(25.00)$ and fruits $(21.00)$ plant $^{-1}$, longest leaf $(11.67 \mathrm{~cm})$, longest root $(5.43 \mathrm{~cm})$ and greater yield of fruits plant ${ }^{-1}(168.30 \mathrm{~g})$. This treatment also produced the tallest plant $(45.33$ $\mathrm{cm})$, maximum flowers plant ${ }^{-1}(2.33)$, longest leaf $(11.55 \mathrm{~cm})$ and higher fresh weight of single flower $(7.34 \mathrm{~g})$ of Dahlia. Compost treatment also significantly influenced various plant characters of Marigold where $75 \%$ compost $+25 \%$ soil $\left(\mathrm{T}_{1}\right)$ gave the tallest plant $(16.33 \mathrm{~cm})$, higher weight of fresh flower $(10.52 \mathrm{~g})$, longest leaf $(10.10 \mathrm{~cm})$ and maximum flowers plant ${ }^{-1}$ (16.33). Plants grown in $100 \%$ compost showed the longest duration in case of Dahlia (19 days) and Marigold ( 23 days) flowering. From the findings, it can be inferred that use of $75 \%$ compost prepared from solid wastes of Mymensingh municipality area plus $25 \%$ soil appeared to be the best practice for obtaining the maximum yield of Chilli, Dahlia and Marigold.
\end{abstract}

Key words: BRRI dhan29, Deep placement, Flooded condition, $\mathrm{N}$ use efficiency and Yield

\section{Introduction}

Flower culture in Bangladesh is comparatively a new venture, but it has been considered as a token of love and beauty from ancient time. The universal usage has created a real trend of producing flower on a commercial basis to meet its increasing demand in the Bangladeshi market (Mannan et al., 2007). Initially a good number of farmers of Jessore, Jhenaidah, Chuadanga, Satkhira and Kustia districts started production of flowers and ornamental plants on commercial basis. The major flowers cultivated by the farmers are rose, tuberose, gladiolus, marigold, dahlia, orchids and lily. The total flower cultivation area is 1,000 acres and total production of flower is 3000 tons with an average yield of $3000 \mathrm{~kg}$ acre $^{-1}$ in 2010-11 (BBS, 2011). Dahlias are native to the subtropical regions of Central and South America.

There are about thirty species in the genus Dahlia, and over 20,000 cultivars are grown (Paun, 2006). Dahlia is one of the most popular and beautiful winter flowering crops belonging to the family Compositae. It is a very attractive ornamental plant, usually grown at borders. They are tender perennials also treated as annuals, consisting of hundreds of cultivars (Kiran et al., 2007; Ahmed et al., 2004). The blooms come in a wide array of colors including white, yellow, orange, pink, mauve and various shades of red. Marigold (Tagetes erecta L.) which occupies a prominent place in ornamental horticulture and is the commercially exploited flower crops belonging to the family Asteraceae. Marigold is broadly divided into two groups, viz. African marigold (Tagetes erecta L.) and French marigold (Tagetes patula L). It is put to many uses like cut flowers, garden displays, garlands, bouquets and for worship. Chilli was introduced into Europe in 1493 by Christopher Columbus who discovered it in tropical America. Chillies were introduced in South Asia in the 1500s and have come to dominate the world spice trade. The lion $\mathrm{s}$ share of Chilli production is taken by India with $36 \%$ share in global production, followed by China $11 \%$, Bangladesh $8 \%$, Peru $8 \%$ and Pakistan $6 \%$ (Karvy, 2008). Chilli (Capsicum frutescens L.), an annual herb or shrub with many branches, belongs to the Solanaceae family. The unripe fruits are green or purple in color but turn red, orange, yellow or brown when ripe (Udoh et al., 2005). It is commonly used as condiments (Alabi, 2006) and the non-pungent species (Capsicum annum) are eaten raw as salad while the stronger flavoured types (Chillies) are popular in all kinds of cookery as pungent species. Chilli is an integral part of our daily life. Among spices and condiments, chilli is the most important and most widely grown spices crop in Bangladesh. The total production of Chilli is 176,000 tons in 2010-11 with an average yield of $6759 \mathrm{~kg}$ acre-1 (BBS, 2011) while world production of Chillies during 2010-11 was estimated to be 29.94 lakh tons (FAO, 2013). Municipal waste management is becoming critically important in modern days. Many countries are trying to find alternatives for traditional land filling and incinerations. More than 15,000 tons of waste is produced in Bangladesh each day. In 2025, it is expected that the number will be 47,000 tons of waste and only a fraction of it will be systematically handled. Importantly, 70$80 \%$ of the municipal solid waste (MSW) is organic and posses a major potential for production of compost fertilizer and biogas. The safe disposal of garbage is a major complex problem in Bangladesh that can affect the air, land, water and environment, as a result different diseases spread. Therefore, proper operation, maintenance and appropriate technology are to be developed to overcome the serious problems by adding proper management and utilization of garbage. Conversion of garbage into valuable organic compost seems to be an immediately solution of the problems 
(Walker and Willson, 1973). Compost is an aerobically decomposed organic material derived from wastage, plants and animal source. It is rich in nutrients, used in gardens, landscaping, horticulture and agricultural field crops (Martens, 2000). Using compost in sustainable agriculture manner preserves agro-ecosystems and environmental quality (Tafaghodinia and Kamalpour, 2008). Agricultural and municipal wastes could be feasible organic nutrient sources for container plant production of flowers. These products are also cheaper, readily available, and could be used to develop artificial soil-based media for container plants. The use of municipal compost for flower production in large scale can solve the problem for disposal of wastes and also solve the lack of organic matter. On the other hand, a judicious combination of compost and soil in pots as a nutrient source might be helpful to obtain a good economic return with good soil health. Therefore, this present investigation was done to evaluate the effect of different levels of municipal waste compost in mix with different levels of soil in pots on the aspect of production of spices Chilli and flowering plants viz. Dahlia and Marigold.

\section{Materials and Methods}

\section{Experimental Site}

The present research work was conducted at the Moinar Mor Sagor Nursery, Mymensingh. The research was carried out during the period from November 2011 to February 2012. The study area is geographically located at about 24 $4^{\circ} 5^{\prime \prime}$ North latitude and 90 50' East longitude (Khan, 1997) having an altitude of $8.3 \mathrm{~m}$ under the Agro-ecological Zone - 9. The soil texture of the experimental site was silty loam, land was medium high and belongs to the AEZ-9 which was originated from Old Brahmaputra deposits, having non-calcareous dark grey flood plain soil. It was fertile and well drained and slightly acidic with $\mathrm{pH}$ varying from 5.5 to 6.8. The climate of the experimental site is subtropical in nature, which is characterized by three distinct seasons, the monsoon extending from May to October, the winter or dry season from November to February and pre-monsoon period hot season from March to April (SRDI, 1991). Plenty of sunshine and moderately low temperature prevails during Rabi season from October to March which is suitable for growing of Chilli, Dahlia and Marigold in Bangladesh.

\section{Treatments of the experiment}

A single factor experiment was consisted of 6 composting levels for the observation of three crops individually (Chilli, Dahlia and Marigold). The six composting levels were as follows: $\mathrm{T}_{0}=100 \%$ compost, $\mathrm{T}_{1}=75 \%$ compost $+25 \%$ soil, $\mathrm{T}_{2}=50 \%$ compost + $50 \%$ soil, $\mathrm{T}_{3}=25 \%$ compost $+75 \%$ soil, $\mathrm{T}_{4}=$ only soil, $\mathrm{T}_{5}=$ Farmers' practice $(75 \%$ recommended rate of NPK + soil)

\section{Experimental design and layout of the experiment}

The experiment was laid out in Randomized Complete Block Design with three replications. Six treatments including a control (soil only) were assigned randomly to the unit pot of $16 \mathrm{~cm}$ long in size. The experimental area was divided into three blocks. Each block consisted of six unit pots. Thus the total number of unit pot was 18 , the blocks and pots were spaced at $1 \mathrm{~m}$ and $0.5 \mathrm{~m}$, respectively.

\section{Methods of flower cultivation}

The selected pots for the experiment were prepared on 27 November 2011 with well decomposed compost and soil. The experimental pots were then properly prepared to provide a good tilth and favorable condition for transplanting of Chilli, Dahlia and Marigold seedlings. Weeds and stubbles were removed from these pots. The pots were leveled and the experimental pots were laid out according to plan. Well decomposed compost was incorporated into pots before 15 days of transplanting as per treatments. The crop in control pot received no chemical fertilizers. In farmers' practice, the crop was fertilized with $75 \%$ of recommended dose of Nitrogen, Phosphorus and Potassium @ 150: 100:125 kg ha ${ }^{-1}$ (6g $\mathrm{ha}^{-1}: 4 \mathrm{~g} \mathrm{ha}^{-1}: 5 \mathrm{~g} \mathrm{ha}^{-1}$ in each pot) in the form of urea, diammonium phosphate and muriate of potash as basal doses as per treatments (BARC, 1997). Twenty seven day old of Chilli and thirty five day old of Dahlia and Marigold healthy and uniform sized seedlings were transplanted in the experimental pots on 03 December 2011 maintaining proper spacing of unit pot. Intercultural operations such as weeding, earthing-up and irrigation was done in different growth stages of plants. Harvesting was done pot-wise during maturity stage. At the maturity stage, whole Chilli fruits were harvested three times at 5 day intervals from first harvest while maximum Chilli fruits were turned into red. Dahlia and Marigold flowers were harvested over a period from 06 February to 04 March 2012. After harvesting, plant height, length of single leaf and single fruit, number of fruits and flowers plant ${ }^{-1}$, duration of flower in plant, weight of flowers and fruits plant ${ }^{-1}$ were recorded in this study.

\section{Statistical analysis}

The recorded data on various parameters under study were statistically analyzed using MSTAT-C computer program according to the principles of experimental design to find out the variation resulting from experimental treatments (Russel, 1986). The means for all the treatments were calculated and analysis of variance for each parameter was performed by F-test (Gomez and Gomez, 1984). The mean values for all the parameters were calculated and the analysis of variance for the characters was accomplished by Duncan's Multiple Range Test (DMRT) at 5\% level.

\section{Results and Discussion}

\section{Effect of different levels of compost on Dahlia}

Plant height of Dahlia was significantly affected by the different compost treatments (Table-1). Each treatment of compost along with different levels of soil produced varying height in response. Treatment combination $\mathrm{T}_{1}$ consisting of $75 \%$ compost $+25 \%$ soil resulted maximum plant height of $45.33 \mathrm{~cm}$ which was significantly different from that of other compost 
treatments. On the other hand, the performance of treatment $\mathrm{T}_{4}(100 \%$ soil $)$ was not satisfactory as it resulted in minimum plant height of $22.00 \mathrm{~cm}$. The length of leaf was significantly affected by the effect of different compost treatments in this study. The mean highest value of leaf size of $11.55 \mathrm{~cm}^{2}$ was recorded in response of $\mathrm{T}_{1}(75 \%$ compost $+25 \%$ soil) while it was statistically similar among with all treatments of compost viz. farmer's practice $\left(\mathrm{T}_{5}\right), 50 \%$ compost + $50 \%$ soil $\left(\mathrm{T}_{2}\right), 25 \%$ compost $+75 \%$ soil $\left(\mathrm{T}_{3}\right)$ and $100 \%$ soil $\left(\mathrm{T}_{4}\right)$ except $\mathrm{T}_{0}(100 \%$ compost $)(11.44,11.10,10.90$ and $10.40 \mathrm{~cm}^{2}$, respectively). Therefore, the shortest leaf $\left(8.33 \mathrm{~cm}^{2}\right)$ was observed in treatment $\mathrm{T}_{0}(100 \%$ compost). There was significant variation in respect of duration of flowering due to the different sources of nutrients or compost. The duration of Dahlia flower had maximum (19 days) in $\mathrm{T}_{0}(100 \%$ compost) which was statistically close by $\mathrm{T}_{1}(75 \%$ compost $+25 \%$ soil $)$ and $\mathrm{T}_{2}$ (50\% compost $+50 \%$ soil) (18 and 17 days, respectively). Among other treatments, the minimum duration of Dahlia flowering (14 days) was obtained from the treatment $\mathrm{T}_{4}$ (solid soil) which was also statistically close (16 days) with both the treatment $\mathrm{T}_{3}$ ( $25 \%$ compost $+75 \%$ soil) and $\mathrm{T}_{5}$ (farmer's practice). Flower production of Dahlia is the main productive and yield characters of Dahlia. It is also the most economic part of the Dahlia. Significant data on the aspect of the production of flowers plant ${ }^{-1}$ of Dahlia were recorded. The maximum number of flowers plant ${ }^{-1}$ (2.33) was obtained from the treatment $\mathrm{T}_{1}(75 \%$ compost $+25 \%$ soil) and the second and third maximum number of flowers (2.00 and 1.67) were recorded from the treatment $\mathrm{T}_{0} \quad\left(100 \%\right.$ compost) and $\mathrm{T}_{5}$ (farmer's practice), respectively. Among other treatments of compost viz. $\mathrm{T}_{2}(50 \%$ compost $+50 \%$ soil $), \mathrm{T}_{3}(25 \%$ compost $+75 \%$ soil $)$ and $\mathrm{T}_{4}(100 \%$ soil) showed similar number of flowers plant ${ }^{-1}$ (1.33). However, treatment $\mathrm{T}_{4}$ (100\% soil) always produces the lower results on the above indicating characters of Dahlia. This result revealed that more Phosphorus, Zinc and other chemical properties of soil increased significantly by applying $75 \%$ compost which was helpful for more flower production. Strojny and Nowak (2004), who noted a greater number of flowers in organic residues with a high Phosphorus concentration Younis et al. (2007) in which those researchers observed that Dahlia coccinea produced more flowers when grown in media featuring maximum phosphorus levels. Adequate phosphorus nutrition enhances many aspects of plant development including flowering, fruiting, and root growth. Similar observation was also found by Khasa et al. (2005) and Carlile (2008) who found that composition and nutritional status of the media (compost + soil) to be helpful for the production of good quality flowering plants with more number of flowers and greater size. There was significant variation was found in respect of fresh weight of flower due to the different compost treatment as a source of soil nutrient. The maximum fresh weight of flower plant ${ }^{-1}(7.34 \mathrm{~g})$ was obtained from the treatment $\mathrm{T}_{1}(75 \%$ compost $+25 \%$ soil $)$ which was statistically close $(7.04 \mathrm{~g})$ with that of obtained from the treatment $\mathrm{T}_{0}(100 \%$ compost $)$. Similarly, treatment $\mathrm{T}_{4}(100 \%$ soil $)$ produced the lower fresh weight of the flower of Dahlia which was also statistically close $(6.67,6.63$ and $6.47 \mathrm{~g})$ among other treatments viz. $\mathrm{T}_{2}$ (50\% compost $+50 \%$ soil $), \mathrm{T}_{5}$ (farmer's practice) and $\mathrm{T}_{3}(25 \%$ compost $+50 \%$ soil), respectively. From the above result, it can be noted that $75 \%$ compost was most effective to enhance the soil nutrient for soil fertility and soil moisture which helped for proper growth of Dahlia flower and resulting the maximum fresh weight of flower. Jothimani and Sangeetha (2012) reported the similar findings who found that the application of human waste compost registered significant differences in the growth characters of Marigold, flower characters and flower yield.

Table 1. Effect of compost treatments as a nutrient source on different yield characteristics of Dahlia at harvest

\begin{tabular}{|l|l|l|l|l|l|}
\hline Treatments & Plant height $\mathbf{( c m )}$ & Leaf size $\left.\mathbf{( c m}^{2}\right)$ & Duration of flower (days) & $\begin{array}{l}\text { Number of } \\
\text { flower plant }\end{array}$ & $\begin{array}{l}\text { Fresh weight } \\
\text { of flower }(\mathbf{g})\end{array}$ \\
\hline $\mathrm{T}_{0}$ & $37.67 \mathrm{~b}$ & $8.33 \mathrm{~b}$ & $19.00 \mathrm{a}$ & $2.00 \mathrm{~b}$ & $7.041 \mathrm{ab}$ \\
\hline $\mathrm{T}_{1}$ & $45.33 \mathrm{a}$ & $11.55 \mathrm{a}$ & $18.00 \mathrm{ab}$ & $2.33 \mathrm{a}$ & $7.340 \mathrm{a}$ \\
\hline $\mathrm{T}_{2}$ & $33.67 \mathrm{c}$ & $11.10 \mathrm{a}$ & $17.00 \mathrm{ab}$ & $1.33 \mathrm{~d}$ & $6.670 \mathrm{bc}$ \\
\hline $\mathrm{T}_{3}$ & $24.00 \mathrm{~d}$ & $10.90 \mathrm{a}$ & $16.00 \mathrm{bc}$ & $1.33 \mathrm{~d}$ & $6.470 \mathrm{bc}$ \\
\hline $\mathrm{T}_{4}$ & $22.00 \mathrm{~d}$ & $10.40 \mathrm{a}$ & $14.00 \mathrm{c}$ & $1.33 \mathrm{~d}$ & $6.230 \mathrm{c}$ \\
\hline $\mathrm{T}_{5}$ & $38.00 \mathrm{~b}$ & $11.44 \mathrm{a}$ & $16.00 \mathrm{bc}$ & $1.67 \mathrm{c}$ & $6.630 \mathrm{bc}$ \\
\hline LSD at 5\% & 2.50 & 1.50 & 2.05 & 0.264 & 0.552 \\
\hline $\begin{array}{l}\text { Level of } \\
\text { significance }\end{array}$ & $* *$ & $* *$ & & $* *$ \\
\hline CV $(\%)$ & 6.87 & $* *$ & 8.76 & 4.50 \\
\hline
\end{tabular}

Figures followed by same letter(s) are statistically identical as per DMRT at 5\% level of probability

$* *=$ Significant at $1 \%$ level of probability

$\mathrm{T}_{0}=100 \%$ Compost

$\mathrm{T}_{1}=75 \%$ Compost $+25 \%$ Soil

$\mathrm{T}_{3}=25 \%$ Compost $+75 \%$ Soil

$\mathrm{T}_{4}=100 \%$ Soil

$\mathrm{T}_{5}=$ Farmers' Practice $(\mathrm{FP})$

$\mathrm{T}_{2}=50 \%$ Compost $+50 \%$ Soil

Effect of different levels of compost on Marigold

Difference sources of compost and soil combination caused significant variation in relation to plant height
(Table 2). The tallest plant of Marigold $(16.33 \mathrm{~cm})$ was obtained from the treatment $\mathrm{T}_{1}(75 \%$ compost $+25 \%$ soil) while it was statistically close $(14.33 \mathrm{~cm})$ to that of 
the treatment from $\mathrm{T}_{0}$ (100\% compost). However, treatment $\mathrm{T}_{4}(100 \%$ soil) observed the shortest plant of Marigold $(9.67 \mathrm{~cm})$ but it was statistically differed among other treatments of the compost. Significant variation was found regarding to the leaf size due to different levels of compost as nutrient source. Among the compost treatment in addition with soil, the leaf size of Marigold did not differed among the combined treatment of compost and soil $\left(\mathrm{T}_{1}, \mathrm{~T}_{2}\right.$ and $\left.\mathrm{T}_{3}\right)$ and also the treatment of farmers' practice $\left(\mathrm{T}_{5}\right)$. However, the treatment $\mathrm{T}_{1}(75 \%$ compost $+25 \%$ soil) was more effective to produce the longest leaf than other treatments while solid soil $(100 \%$ soil or without compost) obtained the shortest leaf $(9.00 \mathrm{~cm})$. These results revealed that all the levels of compost were statistically more or less similar effective on the sizes of leaf of Marigold. This result was also agreement with the findings of Yasmeen et al. (2012) who observed that the leaf area $(\mathrm{cm})$ of carnation plant showed best results in leaf compost + sand. Duration of flower in plant showed significant variation by the effects of various compost levels in addition with solid soil. On the above aspect, $100 \%$ compost or different level of compost in adding with soil $\left(\mathrm{T}_{0}: 100 \%\right.$ compost, $\mathrm{T}_{1}: 75 \%$ compost $+25 \%$ soil, $\mathrm{T}_{2}: 50 \%$ compost $+50 \%$ soil and $\mathrm{T}_{3}: 25 \%$ compost $+75 \%$ soil) and farmers' practice $\left(\mathrm{T}_{5}\right)$ were most effective for longest duration of Marigold flower in plant whereas solid soil (100\% soil) was less efficient for flower duration. As a result, $100 \%$ compost $\left(\mathrm{T}_{0}\right)$ recorded the longest duration of Marigold flower (23 days) which was statistically significant at $5 \%$ level with the treatment of $\mathrm{T}_{1}, \mathrm{~T}_{2}, \mathrm{~T}_{3}$ and $\mathrm{T}_{5}(22,21,22$ and 21 days, respectively) where both the treatment $T_{1}$ and $\mathrm{T}_{3}$ showed same (22 days) duration and also both $\mathrm{T}_{2}$ and $\mathrm{T}_{5}$ showed similar duration (21 days). Flower production plant ${ }^{-1}$ of Marigold is also important part of the flower economy in case of the maximum flower production plant $^{-1}$ enhance the greater yield. So, therefore, flower production plant $^{-1}$ directly related to the greater yield of flower. Analysis of variance data regarding to the number of flower plant ${ }^{-1}$ indicated significant difference due to the effects of various levels of compost. As a result, significantly the maximum number of flowers plant ${ }^{-1}(16.33)$ was obtained from the treatment $\mathrm{T}_{1}(75 \%$ compost $+25 \%$ soil) which were statistically differed among other treatments. On the other hand, the minimum number of flowers plant ${ }^{-1}$ (9) was produced from the treatment $\mathrm{T}_{4}(100 \%$ soil $)$ which was also significantly differed among other treatments. Fresh weight of flower of Marigold is the most important economic part of the Marigold and it was also the most significant characters of the flower yield. It indicated significant differences due to the effects of various level of compost in addition or without addition of soil in respect of fresh weight of flower. Among the treatments, the fresh weight of single Marigold flower had higher $(10.52 \mathrm{~g})$ in that treatment of $75 \%$ compost $+25 \%$ soil $\left(\mathrm{T}_{1}\right)$ while it was statistically similar $(10.06$ g) to that of the treatment of $\mathrm{T}_{0}(100 \%$ compost $)$. On the other hand, the lowest fresh weight of single Marigold flower $(5.71 \mathrm{~g})$ was obtained from the treatment $\mathrm{T}_{4}$ (100\% or solid soil). These results revealed that higher level of compost were most efficient to produce more yield of Marigold flower. It was probably due to the fact that the combination of $100 \%$ compost or $75 \%$ compost and $25 \%$ soil in treatment $\mathrm{T}_{0}$ or $\mathrm{T}_{1}$ provide good soil condition for growth as well as supplied sufficient plant nutrients which helped in production of greater fresh weight of Marigold flower. The application of different levels of vermicompost to Chrysanthemum chinensis resulted increased fresh weight of flowers and flower yield with the application of vermicompost (Nenthra et al., 1999). Shashikanth (2005) noticed in marigold that the application of vermicompost @ $5.0 \mathrm{t} \mathrm{ha}^{-1}$ along with recommended dose of fertilizer had increased flower yield (13.9 tha $\left.{ }^{1}\right)$.

Table 2. Effect of compost treatments as a nutrient source on different yield characteristics of Marigold at harvest

\begin{tabular}{|l|l|l|l|l|l|}
\hline Treatments & $\begin{array}{l}\text { Plant height } \\
(\mathbf{c m})\end{array}$ & $\begin{array}{l}\text { Leaf size } \\
\left(\mathbf{c m}^{2}\right)\end{array}$ & $\begin{array}{l}\text { Duration of flower } \\
\text { (days) }\end{array}$ & $\begin{array}{l}\text { Number of flower } \\
\text { plant }^{-1}\end{array}$ & $\begin{array}{l}\text { Fresh weight of } \\
\text { flower }(\mathbf{g})\end{array}$ \\
\hline $\mathrm{T}_{0}$ & $14.33 \mathrm{ab}$ & $9.67 \mathrm{a}$ & $23.00 \mathrm{a}$ & $13.67 \mathrm{~b}$ & $10.06 \mathrm{a}$ \\
\hline $\mathrm{T}_{1}$ & $16.33 \mathrm{a}$ & $10.10 \mathrm{a}$ & $22.00 \mathrm{a}$ & $16.33 \mathrm{a}$ & $10.52 \mathrm{a}$ \\
\hline $\mathrm{T}_{2}$ & $12.33 \mathrm{~b}$ & $10.20 \mathrm{a}$ & $21.00 \mathrm{a}$ & $9.33 \mathrm{~cd}$ & $8.22 \mathrm{~b}$ \\
\hline $\mathrm{T}_{3}$ & $13.33 \mathrm{~b}$ & $9.95 \mathrm{a}$ & $22.00 \mathrm{a}$ & $11.67 \mathrm{bc}$ & $8.18 \mathrm{~b}$ \\
\hline $\mathrm{T}_{4}$ & $9.67 \mathrm{c}$ & $9.00 \mathrm{~b}$ & $18.00 \mathrm{~b}$ & $9.00 \mathrm{~d}$ & $5.71 \mathrm{c}$ \\
\hline $\mathrm{T}_{5}$ & $12.33 \mathrm{~b}$ & $10.08 \mathrm{a}$ & $21.00 \mathrm{a}$ & $13.33 \mathrm{~b}$ & $8.08 \mathrm{~b}$ \\
\hline LSD at 5\% & 1.85 & 0.648 & 1.94 & 2.41 & 0.915 \\
\hline $\begin{array}{l}\text { Level of } \\
\text { significance }\end{array}$ & $* *$ & $* *$ & $*$ & $*$ \\
\hline CV $(\%)$ & 4.55 & 3.62 & 5.04 & 10.84 & 5.94 \\
\hline
\end{tabular}

Figures followed by same letter are statistically identical as per DMRT at 5\% level of probability

$* *=$ Significant at $1 \%$ level of probability

$\mathrm{T}_{0}=100 \%$ Compost

$\mathrm{T}_{1}=75 \%$ Compost $+25 \%$ Soil

$\mathrm{T}_{2}=50 \%$ Compost $+50 \%$ Soil

\section{Effect of different levels of compost on Chilli}

Analysis of variance data on plant height was significantly influenced by the effect of different level
$\mathrm{T}_{3}=25 \%$ Compost $+75 \%$ Soil

$\mathrm{T}_{4}=100 \%$ Soil

$\mathrm{T}_{5}=$ Farmers' Practice $(\mathrm{FP})$

of compost as a source of nutrients (Table 2). Among the compost treatments, treatment $\mathrm{T}_{1}(75 \%$ compost + $25 \%$ soil) recorded the tallest plant of Chilli $(45.50 \mathrm{~cm})$ 
which was significantly differed among other treatments. In contrast, the shortest plant was obtained from the treatment $\mathrm{T}_{4}(100 \%$ soil $)$ which was statistically at per similar rank with the treatment $\mathrm{T}_{3}$ (50\% compost $+50 \%$ soil) at 5 level of probability. From the above result, it can be prominent that the $75 \%$ compost and $25 \%$ soil showed the best combination of compost and soil than other combinations in case of the tallest plant or proper growth of Chilli was found with this treatment. Besides, higher soil nutrients and proper soil moisture were found by the $75 \%$ compost which ensured the higher growth of Chilli. These results also revealed that compost treatment significantly increased plant height up to $75 \%$ compare to $100 \%$ compost and solid soil. Leaf size showed significant differences by the effect of different level of compost in combination with soil. It was found that the maximum size of leaf $\left(11.67 \mathrm{~cm}^{2}\right)$ was obtained from the treatment $\mathrm{T}_{1}(75 \%$ compost $+25 \%$ soil) while it was statistically identical $\left(11.23 \mathrm{~cm}^{2}\right)$ with the treatments $\mathrm{T}_{0}(100 \%$ compost). These results was also closely $\left(10.43 \mathrm{~cm}^{2}\right)$ followed by the treatment $\mathrm{T}_{5}$ (farmer's practice). On the other hand, significantly the minimum size of leaf $\left(8.17 \mathrm{~cm}^{2}\right)$ was recorded from the treatment $\mathrm{T}_{4}$ (soil only) which was also statistically similar $\mathrm{T}_{1}\left(8.37 \mathrm{~cm}^{2}\right)$ with $\mathrm{T}_{3}(50 \%$ compost $+50 \%$ soil). Analysis of variance data on number of flowers plant ${ }^{-1}$ showed significant difference due to the effects of different compost as soil nutrient. The maximum number of flowers plant ${ }^{-1}$ (25) was obtained from the treatment $\mathrm{T}_{2}(75 \%$ compost $+25 \%$ soil) which was statistically significant (24 and 23) with the treatment $\mathrm{T}_{0}\left(100\right.$ compost) and $\mathrm{T}_{5}$ (Farmers' practice), respectively. The minimum number of flowers plant ${ }^{-1}$ (15) was obtained from the treatment $\mathrm{T}_{4}$ (100\% soil) which was statistically differed from other treatments. The maximum number of flowers plant ${ }^{-1}$ of Chilli was obtained from the treatment $\mathrm{T}_{2}(75 \%$ compost $+25 \%$ Soil). It was probably due to the fact that the combination of $75 \%$ compost and $25 \%$ soil $\left(\mathrm{T}_{2}\right)$ provide good soil condition for growth as well as supplied sufficient plant nutrients which helped in maximum flower production of Chilli plant. Similarly, Morgan (2007) reported that the compost is one of nature's best mulches and soil amendments, and can be used instead of commercial fertilizers. Number of fruits plant $^{-1}$ was significantly influenced due to the application of different level of compost. The maximum number of fruits plant ${ }^{-1}$ (21) was obtained from the treatment $\mathrm{T}_{2}(75 \%$ compost $+25 \%$ soil). Which was statistically close to that the obtained from $100 \%$ compost but significantly superior to that of any other treatment. The minimum fruits production plant ${ }^{-1}(14)$ was obtained from the treatment $\mathrm{T}_{4}(100 \%$ soil or soil only). Which was also statistically similar to that the obtained from $25 \%$ compost and $75 \%$ soil. This result was also showed significantly superior difference among other treatment. It might be due to the fact that $75 \%$ compost in addition to $25 \%$ soil supplying the more nutrients, kept the soil loose and friable, conserved more soil moisture and also maintained proper aeration for better growth of the plant which eventually resulting the more fruits production. Pascual et al. (2010) reported that the organic wastes $(15,30$, and $45 \%$ in peat-based potting mix) increased leaf, shoot, and root dry matter, as well as fruit yield, mainly due to a highe $\mathrm{r}$ number of fruits plant ${ }^{-1}$ of Capsicum annuum L. cv. Piquillo. Tzortzakis et al. 2012 also reported that fruit number increased in S: MSWC 80: 20 without fertilizer in respect of Chilli. Fruit length is also the productive factors of crop as well as the higher length increased the total production. Analysis of variance data on length of fruit was significantly influenced by the application of different level of compost in soil. Length of fruit had higher $(5.43 \mathrm{~cm})$ in combinations of $75 \%$ compost $+25 \%$ soil $\left(\mathrm{T}_{2}\right)$ which was statistically significant difference to that of any other treatment. The lowest length of fruit $(3.20 \mathrm{~cm})$ was obtained from the treatment $\mathrm{T}_{4}(100 \%$ soil or soil only) which was statistically similar to that the $25 \%$ compost and $75 \%$ soil $\left(\mathrm{T}_{3}\right)$. This result was also showed significantly superior difference among other treatment.

Table 3. Effect of compost treatments as a nutrient source on yield characteristics of Chilli at harvest

\begin{tabular}{|c|c|c|c|c|c|}
\hline Treatments & $\begin{array}{l}\text { Plant height } \\
(\mathrm{cm})\end{array}$ & Leaf size $\left(\mathrm{cm}^{2}\right)$ & $\begin{array}{l}\text { Number of flower } \\
\text { plant }^{-1}\end{array}$ & $\begin{array}{l}\text { Number of fruits } \\
\text { plant }^{-1}\end{array}$ & $\begin{array}{l}\text { Weight of fruits } \\
\text { plant }^{-1}(\mathrm{~g})\end{array}$ \\
\hline $\mathrm{T}_{0}$ & $40.30 \mathrm{~b}$ & $11.23 \mathrm{a}$ & $24.00 \mathrm{a}$ & $20.00 \mathrm{ab}$ & $155.0 \mathrm{~b}$ \\
\hline $\mathrm{T}_{1}$ & $45.50 \mathrm{a}$ & $11.67 \mathrm{a}$ & $25.00 \mathrm{a}$ & $21.00 \mathrm{a}$ & $168.3 \mathrm{a}$ \\
\hline $\mathrm{T}_{2}$ & $34.37 \mathrm{c}$ & $9.133 \mathrm{bc}$ & $19.00 \mathrm{~b}$ & $18.00 \mathrm{~b}$ & $145.0 \mathrm{~b}$ \\
\hline $\mathrm{T}_{3}$ & $23.37 \mathrm{~d}$ & $8.367 \mathrm{c}$ & $17.00 \mathrm{c}$ & $15.00 \mathrm{c}$ & $131.7 \mathrm{c}$ \\
\hline $\mathrm{T}_{4}$ & $21.33 \mathrm{~d}$ & $8.167 \mathrm{c}$ & $15.00 \mathrm{~d}$ & $14.00 \mathrm{c}$ & $130.0 \mathrm{c}$ \\
\hline $\mathrm{T}_{5}$ & $39.37 \mathrm{~b}$ & $10.43 \mathrm{ab}$ & $23.00 \mathrm{a}$ & $18.00 \mathrm{~b}$ & $150.0 \mathrm{~b}$ \\
\hline LSD at $5 \%$ & 2.25 & 1.94 & 1.96 & 2.23 & 10.37 \\
\hline $\begin{array}{l}\text { Level of } \\
\text { significance }\end{array}$ & $* *$ & $* *$ & $* *$ & $* *$ & $* *$ \\
\hline CV $(\%)$ & 6.97 & 10.87 & 5.25 & 6.93 & 3.89 \\
\hline
\end{tabular}

Figures followed by same letter(s) are statistically identical as per DMRT at 5\% level of probability

$* *=$ Significant at $1 \%$ level of probability

$\mathrm{T}_{0}=100 \%$ Compost

$\mathrm{T}_{1}=75 \%$ Compost $+25 \%$ Soil

$\mathrm{T}_{3}=25 \%$ Compost $+75 \%$ Soil

$\mathrm{T}_{4}=100 \%$ Soil

$\mathrm{T}_{2}=50 \%$ Compost $+50 \%$ Soil

$\mathrm{T}_{5}=$ Farmers' Practice (FP) 
These results revealed that the combination of $75 \%$ compost and $25 \%$ soil enhance the more nutrients in soil, kept the soil loose and friable and also maintained proper growth of the fruit which increase the fruit size and resulting the higher length. This finding was similar to the findings of Narkhede et al. (2011) who found that vermicompost treatment producing significantly the higher fruit length of chilli compare to organic and soil (control) treatment. Weight of fruits plant $^{-1}$ showed significant difference among the effect of different compost level. The highest weight of fruits plant ${ }^{-1}$ (168.3 was obtained from the treatment $\mathrm{T}_{2} \quad(75 \%$ compost $+25 \%$ soil) which was showed statistically significant difference among the other treatment. On the other hand, the lowest weight of fruits plant ${ }^{-1}$ (130.0) was noticed from the treatment $\mathrm{T}_{4}(100 \%$ soil) which was statistically more or less similar to that of obtained from the treatment $\mathrm{T}_{3}(131.7 \mathrm{~g})$ while they were statistically significant superior to that of other treatment. These results revealed that the higher weight of fruits plant ${ }^{-1}$ directly related to maximum fruits production and fruit length. In case of the treatment $\mathrm{T}_{4}$ (75\% compost $+25 \%$ soil) produced the maximum fruits production and fruit length which will ensured the higher weight of fruits plant ${ }^{-1}$.

\section{Conclusions}

From the present study, it could be concluded that the treatment $\mathrm{T}_{1}(75 \%$ compost $+25 \%$ soil) showed the best compost-soil combination and more effectiveness than other treatments on the aspect of yield and yield attributing traits among the studied crop and flower plants. These results observed that the $75 \%$ compost in combinations with $25 \%$ soil might have enriched the soil chemical and physical properties as soil fertility kept the soil moisture $\mathrm{pH}$ and soil cations favorable which ensured the greater performance of the studied Chilli, Dahlia and Marigold.

\section{References}

Ahmed, M.; Khan, F. M.; Hamid, A. and Hussain, A. 2004. Effect of urea, DAP and FYM on growth and flowering of Dahlia (Dahlia variabilis). Intl. J. Agri. Biol., 6(2): 393-395.

Alabi, D. A. 2006. Effect of fertilizer phosphorus and poultry droppings treatments on growth and nutrient components of pepper (Capsicum annum L.). African Biotech., 5(8): 671-677.

BARC (Bangladesh Agrilcultural Research Council). 1997. Fertilizer Recommendation Guide. Soils Pub. No. 41. 1997. Farmgate, Dhaka: 25 - 184.

BBS (Bangladesh Bureau of Statistics). 2011. Statistics Pocket Book of Bangladesh (2009-10). Bangladesh Bur. of Stat. Div., Govt. People's Repub. Bangladesh. pp. 38-40.

Carlile, W. R. 2008. The Use of Composted Materials in Growing Media. Proc. IS on Growing Media. Acta Hort., 77: 321-328.

FAO. 2013. FAOSTAT. Food and Agriculture Organization of the United Nations. Online available at: online available at:http://faostat.fao.org/site/567/

DesktopDefault.aspx?PageID=567\#ancor)

Gomez, K. A. and Gomez, A. A. 1984. Statistical Procedure for Agricultural Research. Int. Rice Res. Inst. John Wiley and Sons, New York. pp. $139-240$

Jothimani, P. and Sangeetha, R. 2012 Impact of ecosanitation programme and human waste compost on growth and yield of Marigold. Intl. J. Adv. Life Sci., 2: 45

Karvy. 2008. Seasonal outlook on chili. Karvy Special Reports,Karvy Comtrade. http://www. karvycomtrade.com/downloads/karvySpecialRepo rts/karvysSpe cialReports_20080908_01.pdf

Khan, M. S. K. 1997. Effect of different levels of nitrogen on growth, yield and quality of wheat. MS Thesis, Dept. Agron. Bangladesh Agric. Univ. Mymenisngh. pp 35-38.

Khasa, D. P.; Fung, M. and Logan, B. 2005. Early growth response of container grown selected woody boreal seedling in amended composite tailing and tailing sand. Biores. Tech., 96(7): 857864.

Kiran, M.; Baloch, J. and Waseem, K. 2007. Effect of different growing media on the growth and development of Dahlia (Dahlia pinnata) under the agro-climatic condition of Dera Ismail Khan. Pak. J. Biol. Sci., 10(22): 4140-4143.

Mannan, M. A.; Howlader, U.; Bahar, M. H.; Rahman, M. M. and Gain, P. 2007. Present Status of Flower Cultivation and Problems Confronted by the Farmers at Jhikargachha Upazila of Jessore. South Asian J. Agric., 2(1\&2): 89-94.

Martens, D. A. 2000. Management and crop residue influence soil aggregate stability. J. Environ. Qual., 29: 723-727.

Narkhede, S. D.; Attarde, S. B. and Ingle, S. T. 2011. Study on effect of chemical fertilizer and vermicompost on growth of chilli pepplant ${ }^{-1}$ (Capsicum annum). J. App. Sci. Environ. Sanit., 6(3): 327

Nethra, N. N.; Jayaprasad, K. V. and Andkale, R. D. 1999. China aster (Callistephus chinesis (L) Ness) cultivation using vermi compost as organic amended. Crop Res. Hisar., 17: 209-215.

Pascual, I.; Azcona, I.; Aguirreolea, J.; Morales, F.; Corpas, F. J.; Palma, J. M.; Rellán-Alvarez, R. and Sánchez-Díaz, M. 2010. Growth, yield, and fruit quality of pepplant ${ }^{-1} \mathrm{~S}$ amended with two sanitized sewage sludges. J. Agril. Food Chem., 58: 6951-6959.

Paun, L. 2006. Love to know garden. Linkedin.ads (Online available at: http://garden.lovetoknow. com/wiki/Dahlias)

Russell, D. F. 1986. MSTAT-C package programme. Dept. Crop Soil Sci. Michigian State Univ. USA. pp. 59-60.

Sashikanth. 2005. Effect of different sources of nutrients on growth, flowering and seed yield in tall marigold (Tagetes erecta L.) M.Sc. (Agri) 
Thesis, University of Agricultural Sciences, Dharwad.

Strojny, Z. and Nowak, J. S. 2004. Effect of different growing media on the growth of some bedding plants. Acta Hort., 644: 157-162.

Tafaghodinia, B. and Kamalpour, M. 2008. Compost tea. Sepehr (ed.) Persian, Tehran, Iran. 75 p.

Tzortzakis, N.; Gouma, S.; Dagianta, E.; Saridakis, C.; Papamichalaki, M.; Goumas, D. and Manios, T. 2012. Use of Fertigation and Municipal Solid Waste Compost for Greenhouse Pepper Cultivation. Scientific World J., 2012: 1-8.
Walker, M. and Willson, G. B. 1973. Composting sewage sludge; Why? Compost Science. J. Waste Recycl., 14: 10-12.

Yasmeen, S.; Younis, A.; Rayit, A.; Riaz, A. and Shabeer, S. 2012. Effect of different substrates on growth and flowering of Dianthus caryophyllus cv. 'Chauband Mixed'. American-Eurasian J. Agric. Environ. Sci., 12 (2): 249-258.

Younis, A.; Ahmad, M., Riaz, A. and Khan, M. A. 2007. Effect of different potting media on the growth and flowering of Dahlia cocciniacv. Mignon. Acta Hort., 804: 191-196. 